\title{
Waste Generator Actions in Support of the Solid Waste Double Contingency Analysis
}

by

A. Q. Goslen

Westinghouse Savannah River Company

Savannah River Site

Aiken, South Carolina 29808

This paper was prepared in connection with work done under the above contract number with the U.S. Department of Energy. By acceptance of this paper, the publisher and/or recipient acknowledges the U.S. Government's right to retain a nonexclusive, royalty-free license in and to any copyright covering this paper, along with the right to reproduce and to authorize others to reproduce all or part of the copyrighted paper. 


\section{DISCLAIMER}

This report was prepared as an account of work sponsored by an agency of the United States Government. Neither the United States Government nor any agency thereof, nor any of their employees, makes any warranty, express or implied, or assumes any legal liability or responsibility for the accuracy, completeness, or usefulness of any information, apparatus, product, or process disclosed, or represents that its use would not infringe privately owned rights. Reference herein to any specific commercial product, process, or service by trade name, trademark, manufacturer, or otherwise does not necessarily constitute or imply its endorsement, recommendation, or favoring by the United States Government or any agency thereof. The views and opinions of authors expressed herein do not necessarily state or reflect those of the United States Government or any agency thereof.

This report has been reproduced directly from the best available copy.

Available to DOE and DOE contractors from the Office of Scientific and Technical Information, P.O. Box 62, Oak Ridge, TN 37831; prices available from (615) 576-8401.

Available to the public from the National Technical Information Service, U.S. Department of Commerce; 5285 Port Royal Road, Springfield, VA 22161. 


\section{DISCLAIMER}

Portions of this document may be illegible in electronic image products. Images are produced from the best available original document. 


\section{WESTINGHOUSE SAVANNAH RIVER COMPANY INTER-OFFICE MEMORANDUM}

July 30,1997

4A2:ECS-CRST-97-0026

To:

A. M. Vincent, 724-35E

From: A. Q. Goslen, 642-E

(952-2246)

\author{
DOES NOT CONTAIN \\ UNCLASSIFIED CONTROLLED \\ NUCLEAR INFORMATION
}

$\mathrm{ADC}$ and Reviewing Official:

Steve J. Mentrup, Manager, Solid Waste

Approved by $\frac{777 . F \text {. Seule } 2 / 30 / 77}{\begin{array}{l}\text { Marshall F. Perks, Manager } \\ \text { Criticality Safety Engineering }\end{array}}$

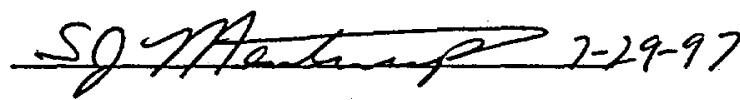

WASTE GENERATOR ACTIONS IN SUPPORT OF THE SOLID WASTE DOUBLE CONTINGENCY ANALYSIS (U)

\section{INTRODUCTION}

In April 1997, a double contingency analysis (DCA) was issued for Solid Waste Management (SWM) transuranic (TRU) waste operations [1]. This DCA includes waste generator compliance with Waste Acceptance Criteria (WAC) fissionable material limits as one defense. This is to be accomplished by the generators accurately characterizing the waste and correctly documenting the contents of each TRU waste container in compliance with the WAC requirements.

This memorandum reviews the methods currently used by the generators to assure compliance with WAC limits for fissile materials in TRU waste. This evaluation does not relieve SWM of the responsibility to provide required initial and periodic reviews of the generator WAC compliance programs with respect to fissionable materials.

\section{SUMMARY}

Facilities that currently send non-negligible quantities of fissionable materials assay their waste. With one minor exception, their current controls are adequate to assure that they meet the requirements of the WAC. The procedures for SRTC have two weaknesses. The procedures allow the drum assays to be done before the drum liners are sealed. Also, individual radionuclide quantities can vary by an order of magnitude in waste assayed by the dose-to-curie method. Otherwise, the facility procedures are adequate when they are followed as currently written. 


\section{SUMMARY (continued)}

Some facilities generate TRU waste that inherently has negligible amounts of fissionable material. Once the amounts of fissionable material from these facilities are demonstrated to be negligible, these facilities require no further evaluation. However, if these facilities initiate significant changes to their operation, such that they can include significant quantities of fissionable materials in TRU waste, then the revised process must be reviewed to verify that they meet the requirements of the Solid Waste DCA.

Some facilities do not generate TRU waste. These facilities require no evaluation unless in future operations they generate waste with fissionable materials that will be sent to the TRU waste facilities.

\section{DISCUSSION}

Scope

This memorandum considers only solid TRU waste currently being sent to the Solid Waste Management facilities. It does not consider criticality safety of activities involving enriched uranium unless that uranium is a co-contaminant in TRU waste. It does not consider criticality safety of low level solid waste. Nor does it include controls for planned future activities.

\section{TRU Waste Generators}

Facilities that generate TRU waste with sufficient potential for excess fissile materials need some means of monitoring and control to support the Solid Waste Double Contingency criticality safety controls. The main SRS facility with current potential to generate TRU waste with significant fissile materials is FB-Line. SRTC also has potential to send significant quantities of fissile materials to the Solid Waste TRU waste facilities. Some other facilities send insignificant quantities of fissionable material to Solid Waste but have the potential to send significant quantities. These facilities include the 772-F laboratory, HB-Line, and the 235-F facility. Plans for HB-Line include generation of TRU waste with significant fissile materials within the next fiscal year. Plans for 235-F include shipment of existing TRU materials to the Solid Waste facilities. These materials (from HB-Line and 235-F) will also require means of monitoring and control to support the Solid Waste criticality safety controls. Current TRU wastes sent to Solid Waste from the HB-Line and 235-F facilities contain only very limited amounts of fissionable materials. In the past, heat load limitations for the ${ }^{238} \mathrm{Pu}$ in wastes from these facilities precluded the wastes from having significant quantities of fissionable materials.

\section{FB-Line Waste}

In FB-Line, TRU waste can contain significant quantities of plutonium. To prevent sending excess plutonium to the TRU waste facilities, all waste leaving FB-Line is assayed. The degree of assay depends on the nature of the waste.

Job control waste (e.g., plastic huts, breathing air hoses, plastic suits) normally has only minor plutonium contamination. These items are placed in a TRU drum liner, the liner is sealed and inserted into a drum, and the drum is sealed. After it is sealed, the drum is monitored on the drum 
DISCUSSION (continued)

\section{TRU Waste Generators (continued)}

FB-Line Waste (continued)

counter to verify that no significant amount of plutonium has inadvertently been placed in the drum. The discard value reported from the assay (used for nuclear criticality safety controls) includes two times the assay standard deviation. These drums normally have less than $0.5 \mathrm{Ci}$ of plutonium contamination. (According to the FB-Line procedures, this is equivalent to 4.39 grams of plutonium.) The drums are allowed to contain more plutonium, but must then be identified for concrete (culvert) storage [2]. The procedures instruct the operators NOT to attempt to compress the waste in the drum liner, as this may puff contamination out of the waste bags and into the work area. The procedures also include limits on surface contamination, such that excess contamination triggers use of another procedure $[3,4]$ that includes a separate assay of the waste drum contents. Future plans for FB-Line include installation of a gamma counter (called a $Q^{2}$ counter) that will also be used to assay the drums with job control waste [5, 6]. Use of the $Q^{2}$ counter could remove the reliance on the drum counter.

Although much effort is made to minimize the plutonium in the waste, FB-Line process waste frequently has significant quantities of plutonium. FB-Line process waste also has one of the greatest potentials for unintended shipment of excess plutonium in the TRU waste. To prevent unintended shipment of plutonium to Solid Waste, FB-Line provides two assays of most process waste, by independent methods, prior to placing the waste in the drum [7]. A third measurement on a drum counter, after the drum and drum liner are sealed, provides a final check to verify that there is no unintended plutonium in the TRU waste drum $[8,9]$.

During the waste handling operations, the waste is double bagged as it is removed from the processing lines. The bagged waste is placed in a five gallon pail that has been painted red for easy identification as waste. (This memorandum will subsequently refer to these buckets as red pails, and this waste as red pail waste.) The red pail is then sealed, and handled individually, one pail at a time, to comply with FB-Line criticality safety requirements.

The red pail is taken to the assay room. Before going into the assay room, it receives a passive neutron scan to assure that it will not exceed the posted mass limit for the assay room. Once in the assay room, waste is placed into each of two assay machines. One of the assay machines is a neutron coincidence counter (NCC). The other assay machine is a segmented gamma scanner(SGS) [7]. The discard value reported from the assay (used for nuclear criticality safety controls) includes two times the assay standard deviation. (For example, if an item assayed at 23.34 grams, with a standard deviation of 0.47 grams, the reported discard value would be 24.28 grams.)

The SGS operates by scanning for gamma emissions from ${ }^{239} \mathrm{Pu}$ decay in individual segments of the waste. The assay computer determines the total plutonium based on the isotopic composition estimated from laboratory analyses. (This value is entered into the computer by the assay operator.) The SGS turntable both rotates the waste, and adjusts the elevation within the machine, so that the assay can accurately account for variations in vertical distribution. The gamma scan includes detection and adjustment for attenuation through dense portions of the waste. This is 
DISCUSSION (continued)

TRU Waste Generators (continued)

FB-Line Waste (continued)

accomplished by including a scan for gamma radiation from a ${ }^{75} \mathrm{Se}$ source placed on the opposite side of the assay chamber from the detector. The SGS also corrects for count-rate-related losses caused by dead time and pulse overlap. This correction uses the known constant interaction rate from a known ${ }^{109} \mathrm{Cd}$ source fixed to the detector. Calculations and results from the SGS are independently reviewed and verified [10].

The NCC operates by detecting the neutrons emitted during spontaneous fission in ${ }^{240} \mathrm{Pu}$ [11]. The assay computer determines the total plutonium based on the isotopic composition estimated from laboratory analyses. (This value is entered into the computer by the assay operator.) The accuracy depends on knowledge of the ${ }^{240} \mathrm{Pu}$ percentage in the $\mathrm{Pu}$, and the material matrix (oxide and fluoride). The precision depends on the quantity of plutonium in the sample. An appropriate standard is used to verify the instrument calibration before and after a series of assays. The standard is chosen according to the material to be assayed: one calibration standard is available for waste assays. Also, the NCC performance is checked with a ${ }^{252} \mathrm{Cf}$ source within 7 days preceding the assay.

For red-pail waste, FB-Line uses generally conservative results for the mass of plutonium discarded. The value reported is the larger result from the two assay methods (NCC and SGS). Two sigma (twice the standard deviation of the assay) is added to the assay result to determine the discard value [12].

When sufficient waste cuts are available for packaging, waste cuts are selected according to the drumming segregation report [8]. (The drumming segregation report is generated by the FB-Line Supervisor, and independently reviewed by the FB-Line cognizant engineer. The report identifies which red pail waste cuts may be packaged in a single drum while remaining in compliance with waste criteria for the drum.) One of the selection criteria is to limit the drum loading to 150 grams of plutonium [3]. The selected red pails are opened (one at a time), and the waste placed into a drum liner. The procedures instruct the operators NOT to attempt to compress the waste in the drum liner, as this may puff contamination out of the waste bags and into the work area. Once the liner is filled with the selected cuts, it is sealed and placed into a TRU waste drum. The drum is sealed and transported to the drum counter. The drum counter provides a final check of the quantity of plutonium in the waste.

Reference [3] provides instructions for handling process waste that will not fit in the red pails. When removed from the cabinets, these wastes are bagged and placed into drum liners. A far-field gamma assay by a portable gamma monitor determines the quantity of plutonium in each drum liner [13]. The procedure requires an independent verifier signature for the quantities reported. The discard value reported from the assay (used for nuclear criticality safety controls) includes two times the assay standard deviation.

Heavy metals can obscure the plutonium gamma emissions. One major source of heavy metal in the FB-Line facilities is lead-lined gloves. Because the gloves do not fit in the red pails, they receive only the gamma scan. Section 4.9 of reference procedure [3] provides instructions for 


\section{DISCUSSION (continued)}

\section{TRU Waste Gẻnerators (continued)}

FB-Line Waste (continued)

packaging lead-lined gloves into a TRU drum liner. These instructions tell the operators to place the gloves near the center of the drum, with plastic waste placed around the circumference. This improves the accuracy of waste assays in drums with lead lined gloves. With the gloves centered in the drum, attenuation of the gamma radiation used in the assays is minimized.

Some waste items will not fit in the 55-gallon drums. These items are placed in plywood boxes. HEPA filters are placed in polyethylene boxes. The plywood boxes are subsequently placed in large steel boxes for storage in the Solid Waste facilities[14, 15, 16]. The polyethylene boxes and plywood boxes are assayed using a portable gamma detector $[17,18,19]$. The procedure for the steel boxes specifies that they contain less than 150 grams of plutonium. The quantity is manually tallied in the procedure. The procedure for the HEPA filter polyethylene boxes instructs operators to notify supervision for actions to take if the boxes assay greater than 150 grams of plutonium. Solid Waste management experience indicates that the HEPA filters normally contain less than 100 grams of plutonium [20]. The filters that contain more contamination come from a process upset in which the prefilters ruptured. This incident caused four HEPA filters to contain atypical quantities of between 240 and 340 grams of plutonium.

\section{SRTC Waste}

In SRTC, fissionable materials released to TRU waste are restricted to very small quantities. The accountability discard limit is 25 grams of fissionable material per month for all of SRTC [21]. Additionally, SRTC restricts fissile material loading to 15 grams per 55-gallon drum. SRTC also limits B-25 boxes to 15 grams of fissile materials. These constraints are included in the TRU waste discard procedure [22]. Release of larger quantities requires special reviews and approval by DOE and by the SRTC waste coordinators. For much of the SRTC waste, quantities are determined on the Canberra $Q^{2}$ assay system. The quantity reported in the assayed waste includes an allowance for assay error, of two times the assay uncertainty. However, the procedures do not specify when the assay is done. Drums may be assayed before the drum liners are sealed. This makes it possible for more material to be added to a drum between the time of assay and the time the drum liner is sealed.

Some SRTC waste has radiation rates too high for assay in the $Q^{2}$ system. For this waste, SRTC uses dose-to-curie conversion factors to determine the curie contents of the containers. (For known isotopic composition, the curie values can be converted to gram values.) The dose-to-curie methodology has significant uncertainties. The true value can be different from the assay value by as much as an order of magnitude [23].

\section{Facilities with Negligible Fissile Material in TRU Waste}

Many SRS facilities that generate solid TRU waste place negligible quantities of fissionable material in their solid waste. These facilities include the Central Laboratory Facilities (772-F and associated buildings), F-Area Outside Facilities (211-F), the F Canyon (221-F) facility, and the H Canyon (221-H) facility. 
DISCUSSION (continued)

Facilities with Negligible Fissile Material in TRU Waste (continued)

Materials in the Central Laboratory Facilities (CLAB) are well characterized. The CLAB analyzes process support samples from many site facilities. Most of the sample volume is returned to the process, so that negligible fissionable material is available as solid TRU waste. The TRU waste tends to be mostly ( $70 \%$ by volume) plastic items, with lesser amounts of paper ( $20 \%$ by volume), and ( $10 \%$ by volume) glass and metal. Typical CLAB waste drums contain only 1-2 grams of TRU contaminants. The drum liners are assayed by a gamma scan before they are placed in drums and sent to the Solid Waste facilities [24].

Laboratory drains return the materials to F-Canyon or F-Area Outside Facilities tanks. The drain tanks are frequently flushed with acid to prevent accumulation of fissile materials. The 211-F Outside facilities (including FA-Line) handle only negligible quantities of TRU contamination. The bulk of the 211-F waste is either recycled to the 221-F canyon processes, or routed to the $241-F$ high-level waste tanks. The only solid waste normally generated in $211-F$ is low-level job control waste. (If the 800-series tanks have mechanical or hydraulic cleanout, TRU waste might be generated. These tanks include the CLAB drain tank. In the event of such a cleanout, it will be necessary for any TRU waste generated to be evaluated for fissionable material content. These tanks are normally cleaned by acid rinses.)

It is considered unlikely that TRU waste will be generated in the F-Canyon facilities. If TRU waste is generated, Solid Waste should review the controls used to assure the absence of unacceptable quantities of fissile material

A search of the COBRA database records showed no TRU waste receipts from the F-canyon facilities since 1977 [20] except from the FB-Line facilities. Except for the FB-Line facilities, the F-Area Separations facilities (211-F and 221-F) wastes contain essentially depleted uranium. The low-level waste characterization forms for these facilities show the ratios of various nuclides in the waste $[25,26]$. The uranium in this waste has less than 0.22 weight $\%{ }^{235} \mathrm{U}$, with minor plutonium contamination. It is not likely to be TRU waste.

It is also considered unlikely that TRU waste will be generated in the H-Canyon non-B-Line facilities. If TRU waste is generated, Solid Waste should review the controls used to assure the absence of unacceptable quantities of fissile material.

A search of the COBRA database records showed only one TRU waste receipt from the H-canyon non-B-Line facilities since 1977 [20]. Review of the COBRA printout shows that this container is most likely miscoded in the records. The container is the wrong type for TRU waste, the contamination is listed as being fission products, and the coordinates do not match the TRU pad locations.

Unlike the F-Canyon waste, the uranium in the H-Canyon waste is enriched uranium. (The uranium concentrations tend to be low, trace quantities, so that there is normally not a criticality concern.) If TRU waste is received from the $\mathrm{H}$-Canyon facilities, there will be a need to verify the fissile material quantities in the waste. 
DISCUSSION (continued)

\section{Facilities without TRU Waste}

Many facilities at SRS do not currently generate TRU waste though they either handle radioactive materials or were designed to handle radioactive materials but currently do not. These facilities are outside the scope of this review. The following paragraphs present the background information that shows why facilities generate no TRU waste. Specific facilities that do not currently generate TRU waste include Naval Fuels (247-F), New Special Recovery (NSR), the High Level Waste Tank Farms, the Defense Waste Processing Facilities (DWPF), Tritium Facilities, the Consolidated Incineration Facility (CIF), TNX, H-Area Outside Facilities (211-H, including HA-Line and the Enriched Uranium processing Facilities (EU)), the Receiving Basin for Offsite Fuels (RBOF), and the Raw Materials facilities. The Reactor facilities do not normally generate TRU waste, but there has been one exception in 1997.

The tritium facilities, the NSR facilities, and TNX do not contain fissile materials. NSR was never placed in service. The only fissionable material used in the tritium facilities is depleted uranium. Though ${ }^{238} \mathrm{U}$ can be fissioned with fast neutrons, it can not sustain a chain reaction. The TNX facilities do not have any TRU materials.

CIF does not handle TRU waste. The CIF waste acceptance criteria (WAC) and procedures prohibit acceptance of TRU waste in CIF.

The High Level Waste facilities do have TRU isotopes. However, in the HLW tank farms and in DWPF, the TRU isotopes constitute only a small portion of the radionuclides. The much greater concentrations of fission product radionuclides ensure that materials from these facilities will be high level waste if the materials have enough fissionable materials to be TRU waste. The Solid Waste facilities do not normally accept high level waste. (In the single case when high-level materials were accepted, they were materials from SRTC. They were accepted only for temporary storage pending processing in another facility [27].) The High Level Waste facilities do not currently send TRU waste to the Solid Waste facilities.

It is possible that the HLW facilities may generate TRU waste in the future. This waste will have high radiation from fission products, and will require heavy shielding to avoid being remotehandled TRU waste. If HLW sends TRU waste to the Solid Waste facilities, then the waste must be evaluated for criticality safety, and may require assay to determine the quantity of fissionable materials present.

The 247-F (Naval Fuel) facilities, and part of the 211-H outside facilities, have highly enriched uranium, but no TRU materials. The $247-\mathrm{F}$ facilities specifically handled highly enriched uranium, and no other radioactive materials. The $247-\mathrm{F}$ process facilities have been deactivated and de-inventoried. Only residual contamination may remain in these facilities.

The 211-H outside facilities handle cold (non-radioactive) feed to the 221-H canyon, some low-activity waste activities that need no radiation shielding, and the now inactive uranium solidification (USF) project. The USF handled enriched uranium, and some enriched uranium solutions are still present in these facilities. 
DISCUSSION (continued)

Facilities without TRU Waste (continued)

Though wastes from these facilities are not TRU wastes, they can have fissile materials.

Acceptance of waste, for storage on the TRU pads, with significant fissile material contamination from these facilities, will require special evaluation as part of the USQ process, to determine if the waste may pose any criticality concerns.

Solid wastes from RBOF and the Reactor areas do not contain significant quantities of fissionable materials and normally are not TRU waste. The fissionable materials in these facilities are normally contained within the fuel. Solid Waste does not accept reactor fuel. Normally, the only wastes from these facilities, with potential to contain fissionable materials, are ion exchange resins and sludge that has accumulated in the bottom of the fuel basins.

If fuel elements have had leaks in the past, then some fissionable material contamination may be present in the sludge. Receipt of the sludge into the Solid Waste facilities will require evaluation through the USQ process. If the sludge is ever sent to Solid Waste, the USQ process is expected to review the potential for the sludge to contain TRU or fissionable materials.

The current Basis For Interim Operations (BIO) document [29] for the reactors shows that there is no potential for criticality in the deionizers, and that the water drawn into the deionizers does not contain detectable quantities of fissile nuclides. The absence of fissile nuclides in the deionizer resins indicates that the resins will not present any criticality concerns if they are stored as TRU wastes.

One recent waste shipment from the reactor areas did have TRU waste. A shipment contained

${ }^{241} \mathrm{Am}$ sources[28]. This is not a normal shipment for the reactor areas. The americium was being disposed at the request of the Health Protection group in the reactor areas. The total fissionable material involved was less than one tenth of a gram.

The raw materials facilities at one time contained significant quantities of fissile materials. These facilities have been de-inventoried. Normal wastes from these facilities will not contain fissile or TRU materials. If the facilities are dismantled, it is possible that waste from dismantling operations may be contaminated with significant quantities of fissile materials. If dismantlement waste from these facilities is sent to Solid Waste, the receipt will require evaluation through the USQ process, including review of the potential impact of fissionable material contamination.

\section{Off-Site Generators}

Receipt of TRU waste from off-site generators is handled on a case-by-case basis, with careful documentation of the fissionable material quantities. No off-site generators are currently sending TRU waste [27]. The most recent off-site TRU receipt was a plutonium-beryllium neutron source from Aiken Technical College $[30,31]$. This source contained $0.4 \mathrm{~g}$ of ${ }^{238} \mathrm{Pu}$ and $0.1 \mathrm{~g}$ of other plutonium isotopes. The next most recent off-site TRU waste receipt was a set of measurement standards from the National Institute of Standards (NIS) in 1993 [32]. The total fissionable material in the NIS shipment was less than 200 grams, of which less than 50 grams was fissile. 


\section{REFERENCES}

[1.] N-NCS-E-00005, "Nuclear Criticality Safety Evaluation: Double Contingency Analysis", Solid Waste Management Facility Transuranic Waste Storage Pad and Waste Storage Pad Operations (U)", K. E. Hammer, April 1, 1997.

[2.] Procedure SOP 221-FB-2506-NS, "Packaging TRU HUT Waste (Excluding Process Cabinet Waste) and TRU Contamination Waste into a TRU Drumliner (U)", Rev. 19, 12/12/96.

[3.] Procedure SOP 221-FB-2505-NS, "Packaging TRU (Process Cabinet) Waste into a TRU Drumliner $^{1}$ (U)", Rev. 13, 10/22/96.

[4.] Procedure SOP 221-FB-2502-A-NS, "Packaging General and Cabinet Waste Into a Red Pail (U)"

[5.] Electronic message, Lloyd Hedlund to Andrew Goslen, "Re[5]:Waste Generators Compliance Memorandum (U)", July 24, 1997.

[6.] Electronic message, Don Faison to Andrew Goslen, "Re[7]: Waste Generators Compliance Memorandum (U)", July 23, 1997.

[7.] Procedure SOP 221-FB-2502-B-NS, "Transporting, Assaying, and Storing Red Pail Waste (U)", Rev. 9, 2/4/97.

[8.] Procedure SOP 221-FB-2504-NS, "Drumming Red Pail Waste for Shipment to Solid Waste Disposal Facility (U)", Rev. 16, 6/26/97.

[9.] Procedure SOP 221-FB-2507-NS, "Measuring 55-Gallon Waste Drums on the Drum Counter (U)", Rev. 2, 10/3/94.

[10.] Procedure L3.3-10014, "Red Pail SGS Operations, FBL (U)", Rev. 2, 12/07/94.

[11.] Procedure L3.3-10023, "Red Pail NCC Operations, FBL (U)", Rev. 0, 12/07/94.

[12.] Procedure L3.3-10022, "Red Pail TRU Waste Calculations, FBL (U)", Rev. 0, 11/22/96.

[13.] Procedure SOP 221-FB-2552-NS, "Portable Gamma Detector Assaying of Drumliners in FB-Line (U)", Rev. 4, 3/21/96.

[14.] Procedure SOP-221-FB-2508-NS, "Packaging and Handling HEPA Filter Waste (U)", Rev. 11, 11/27/95.

[15.] Procedure SOP-221-FB-2512-NS, "Packaging Waste Into a Plywood Burial Box (U)", Rev. 10, 9/9/96.

[16.] Procedure SOP 221-FB-2518-NS, "Loading TRU Waste Into Steel Burial Boxes (U)", Rev. 2, 7/14/93. 


\section{REFERENCES (continued)}

[17.] Procedure SOP 221-FB-2550-NS, “Portable Gamma Detector Assaying for HEPA Filters in FB-Line (U)", Rev. 1, 9/24/94.

[18.] Procedure SOP 221-FB-2551-NS, "Portable Gamma Detector Assaying for Burial Boxes in FB-Line (U)", Rev. 1, 9/24/94.

[19.] Procedure SOP 221-FB-2551-A-NS, "Portable Gamma Detector Assaying for Burial Boxes not on Third Level in FB-Line (U)", Rev. 1, 9/24/94.

[20.] Computerized Radioactive Waste Burial Records Analysis System (COBRA) database records.

[21.] Manual L17.2, Section CTS-86-1, "SRTC/LOD TRU Waste Procedure", Rev. 12, 5/1/97.

[22.] Manual L7.13, Procedure 001, "TRU/WIPP Waste (U)", Rev. 0, 8/23/95.

[23.] WSRC-TR-96-0343, "Waste Characterization Plan for 773-A Shielded Cells Low-Level Waste Casks (U)", Rev. 1, P. E. Filpus-Luyckx, November 18, 1996.

[24.] TSD-ALA-97-030, "TRU Waste Packaging from the Central Laboratory Facilities (U)", J. Satkowski to A.M. Vincent, March 31, 1997.

[25.] WSRC-TR-94-0516, "Radioisotope Characterization of F-Canyon Low-Level Waste (U)", Rev. 2, S. J. Brown and R. H. Spires, July 31, 1996.

[26.] Addendum to WSRC-TR-94-0516, "Radioisotope Characterization of F-Canyon Low-Level Waste Revision 2, Correction of A-Line Waste Stream Distribution", S. J. Brown and R. H. Spires, April 10, 1997.

[27.] Personal communication, S. J. Mentrup to A. Q. Goslen, 6/5/97.

[28.] Q-CLC-M-00044, Rev. 1, Engineering Calculation, September 25, 1996.

[29.] WSRC-TR-94-207, Rev. 0, "Basis for Interim Operation for K-Reactor in Cold Standby (U)", T. C. Easterling and C. E. Morgan, Jr., February 1995.

[30.] Form OSR 16-1-W (Rev. 5-89), "Interdivisional Nuclear Material (NM) Transfer Report, WSRC - Savannah River Site”, No. 124867

[31.] Special Procedure SP-SW-50, "Storage and Overpackaging of Aiken Tech Drum (U)", May 8, 1996.

[32.] Burial slips, Form OSR 7-375, numbers 595647, 595648, 595649, and 595650, October 1993. 
CC: C. E. Apperson, 730-2B

M. F. Perks, 706-F

S. J. Bellamy, 707-F

R. T. Burns, 221-H

C. E. Goergen, 221-H

T. C. Robinson, Jr., 221-F

W. E. Lloyd, Jr., 221-F

T. C. Hasty, 235-F

A. P. Mock, 703-F

R. M. Mobley, 704-2H

D. R. Johnson, 704-2H

W. E. Harris, Jr., 221-F

J. A. Blankenhorn, 724-9E

D. W. Zimmerman, 724-7E

W. A. Morrison, Jr., 724-7E

A. Gibbs, 724-21E

H. W. Coleman, 724-9E

S. J. Mentrup, 705-3C

L. A. Hedlund, 707-F

M. A. Rosser, 707-C

J. S. Bullington, 707-F

J. N. Joshi, 707-F

D. M. Faison, 772-3F

T. E. Baldwin, 221-H

R. J. Orkney, 221-H 